\title{
A Survey of Communication Apprehension in English Among Engineering Students
}

\author{
Aisha Faryal (corresponding author) \\ English Language Development Center \\ Mehran University of Engineering \& Technology Jamshoro, Sindh, Pakistan \\ E-mail: faryalaisha786@gmail.com \\ Habibullah Pathan (Co-author) \\ English Language Development Center \\ Mehran University of Engineering \& Technology Jamshoro, Sindh, Pakistan \\ E-mail: habibullah.pathan@faculty.muet.edu.pk \\ Amina Bibi Bhatti (Co-author) \\ English Language Development Center \\ Mehran University of Engineering \& Technology Jamshoro, Sindh, Pakistan \\ E-mail: preciousss123@gmail.com \\ Aisha Bhatti (Co-author) \\ English Language Development Center \\ Mehran University of Engineering \& Technology Jamshoro, Sindh, Pakistan
}

Received: March 13, 2019

Accepted: May 22, 2019 Published: May 24, 2019

doi:10.5296/elr.v5i1.14833

URL: https://doi.org/10.5296/elr.v5i1.14833

\begin{abstract}
In Pakistan, English is used as a second language in all academic and professional domains. Achieving oral fluency becomes obligatory for students so that they can proficiently
\end{abstract}


participate in the formal discussions, debates and presentations. Communication Apprehension is the fear of speaking. It hinders the speakers from communicating confidently and fluently. The purpose of this paper is to explore the feelings of students during communication and to identify the level of oral communication apprehension faced by engineering students. In this study, quantitative method was used to measure communication apprehension among the respondents. Data was collected through surveys by using random sampling procedure and analysed through the SPSS software. An adapted version of McCroskey PRCA-24 instrument was used to conduct data, 18 items were selected according to requirement of this study. The questionnaire comprises of twenty-four items for respondent's feelings while their communication with peers majorly in four tasks of communication: group discussions, meetings, interpersonal conversations and public speaking.

The "meeting" section was omitted. The questionnaire was developed to measure the respondents' communication apprehension in the above stated communicative tasks. The findings of the study show that the students have high communication apprehension during participation in public speaking and formal discussions whereas low apprehension was reported during participation in group discussions.

Keywords: Oral communication apprehension, Communication skills

\section{Introduction and}

\subsection{Background of the Study}

In the era of globalism, English is having the status of a global and economical language and its spoken all around the world. In Pakistan, English is spoken as a second language and is an official language of the country. It plays an important role in educational and professional settings. English is considered as one of the keys to get success for professionals. So, it is crucial need of today to have a good and proficient English to get good grades in educational settings and to have a flourishing occupational career.

In the field of engineering, communicative competence is a need, or in other words the demand, of work place and an important skill required for good presentation in professional settings. Therefore, in the field of ELT, it is the job of an ELT teacher to devise a course which can fulfil the needs of learners and make them competent in communicative skills for the field work.

In the context of second language learning, communication apprehension is a major issue for the learners of English as a second language.

Berger, McCroskey and Baldwin (1984, as cited in Devi \& Feroz, 2008) defined communication apprehension as "the way a person feels about communication, not how they communicate". Furthermore, they elaborated that anxiety in communication could be because of lack of proficiency in TL, insecurity or lack of practice.

Apprehension is a fear or anxiety of speaking which hinders the process of interaction and communication. This is an issue of concern for ELT teachers and for students to get rid of 
such apprehension in order to meet the demands of occupational needs. Not only this, communication apprehension likewise hinders the student participation in class discussion and prompts students to avoid questioning. Consequently, students are unable to perform efficiently during their academic period and even when the students enter into the professional life, they face difficulties if they fail to have good communication skills. In a country like Pakistan, proficient English is the priority and an obligation for getting a good job. So, it will be not wrong to say if anyone has poor English means he or she has a poor future.

This study aims to investigate the level of communication apprehension and the related problems of engineering students of MUET.

\subsection{Aims \& Objectives}

The current study aims to identify the oral communication apprehension faced by undergraduates of MUET.

On the basis of this, the following objectives were set:

- To know the feelings of students during communication.

- To identify the level of oral communication apprehension faced by engineering students.

\subsection{Research Questions}

Based on the research objectives, the following research questions were designed:

- What do students feel while communicating in English?

- What is level of apprehension when students interact with others in English language?

\subsection{Significance of the Study}

The study benefits the field of ELT and ESP. The purpose of this study is to investigate the reasons behind students failing to communicate properly. Communication is one of the most important skill in teaching a language. Unfortunately, in our teaching context, it is an untouched area as most of the course material is heavily focused on writing skills. Especially learning in second or foreign language, it requires extensive effort to be proficient enough to speak confidently and fluently. In our context, students of undergraduates encounter many problems when dealing with speaking in English for class room participation, interviews and field work. In order to design such courses that give benefit to students for their professional life, an ESP practitioner must know all the factors, causes and hindrances that learners encounter in gripping any language skill. As discussed that communication is an obligatory skill for workplace and fieldwork professionals, so it is crucial for an ESP teacher to devise the activities and course accordingly in order to make the process of learning beneficial and successful for professionals.

\section{Literature Review}

\subsection{Communication Apprehension (CA)}


Communication apprehension can be observed as an internal, affective response with external, observable impact on communication behavior. The construct of "communication apprehension" evolved from the earlier reticence conceptualization. The original conceptualization, which has remained unchanged, viewed communication apprehension as the "fear or anxiety associated with either real or anticipated communication with another person or persons."(McCroskey \& Richmond, 1982).

It is estimated by most of the communication experts that about 2 out of 10 individuals are observed to face the communication anxiety. (Watson and Bossley, 1995, as cited in Kaur et al. 2011).

Tunaboylu (1993, as cited in Kaur et al., 2011) explains that students have the "tendency to be silent listeners rather than active speakers in oral English classes is caused by several reasons. The most prominent of these reasons is psychological pressure of making mistakes in the presence of their classmates. The other would be poor count of vocabulary. So, CA is attributed to students "fear of poor communication and negative evaluation".

McCroskey et al. (1999) conducted a study on levels of CA among Japanese students in native and second language (English). The results are a good evidence that Japanese students encounter high CA in native and English language.

Larsen-Freeman and Long (1991) found that communicative language situation can be influenced by evaluation that leads to uncertainty and anxiety. In the context of oral communication skills, which are vital in all study areas, CA has deleterious effects on classroom participation and academic success since teachers reward students who take part in classroom participation and demonstrate academic success with good marks (Kaur et al. 2011).

The study conducted by Kaur et al. (2011) in Malaysia, on a female student from Indonesia, recorded the highest overall communication apprehension score, 70. It is clear that the participant of this study had high communication apprehension level and this is further strengthened by the high scores that were recorded in all three areas of communication: group discussion, interpersonal conversation and public speaking. This could be attributed to the fact that this participant did not obtain any prior instruction in English in her native country. The respondent's only exposure to English in Malaysia was through the six months of language classes under the Intensive English Programme, before registering for the degree programme. Poor command of the English language and a basic level of vocabulary may have contributed to her anxiety and weak communication skills.

MacIntyre \& Noels (1997) examine that the individuals who have low L2 communicative competence are observed as highly anxious while communicating in target language.

In Puerto Rico, a study was conducted by Richmond et al. (2008) with Puerto Rican learners of English as a second language. The results concluded that these pupils were more apprehensive when communicating in (L2) English, compared to using their L1 (Spanish). Furthermore, their self-perceived competence and the level of communication apprehension in L2 was considerably correlated. 
Thaher (2005) discussed the factors that increase CA in an English language classroom, especially EFL classroom, there are three groupings: (1) psychological factors, which are anxiety, self-esteem, emotions, attitude, fear and motivation; (2) instructional factors, which are teacher, goals, method, text, time, and means of evaluation, and (3) sociocultural factors, which are, social distance, acculturation, second versus foreign language learning and culturally accepted thought. Additionally, this study mentions that in the area of verbal communication skills, which are crucial in all study areas, CA has undesirable effects on classroom participation and academic success since teachers reward those learners who take part in classroom and determine academic success with good marks (Thaher, 2005).

According to national survey conducted by Winsor, Curtis and Stephens (1997, as cited in Devi \& Feroz, 2008) of 1000 human resource managers, it was recognized that oral communication skills are valued for both obtaining job and successful job performance. Moreover, Boyer commission (2003, cited in Devi \& Feroz, 2008) writes that faculty members and administrators are concerned about the graduates with poor oral communication skills and they highlighted that there is growing expectation that universities should meet the needs of industry and produce engineers who are communicatively competent. With regards to prior studies, Corello (2000, Devi \& Feroz, 2008) pointed out that "individuals with high CA rated their own self-competence at performing specific communication skills lower than others and also recognized that when the students are confident on their competency, they perform better in their presentations and teachers award them better grades. The results of this study shows that students who are communicatively competent have lower level of CA and they managed to perform better in class presentations.

The study conducted from a Malaysian electrical engineering students by Devi and Feroz (2008) reported four major findings of their study. First, the undergraduates have moderate level of CA while presenting in classroom; secondly, students possess average communicative competence in all categories, as in meetings, friends, public and groups; and thirdly, students are modest speakers and ranked at 9 to 16 marks above the score they suggested and if ample practice was given, these students has potential to become competent speakers in future, and fourthly, if communicative competence of students is high then the CA comes to lower level.

According to Grant and Dickson (2006, cited in Raha, N. Radzuan, M and Kaur, S. 2010) the World Chemical Engineering Council (WCEC) surveyed 2158 chemical engineers from 63 countries in 2004, on general aspects and abilities in relevance to workplace needs, found that the ability to communicate proficiently was ranked third from 26 other enumerated attributes. The answers proves the significance of communication skills as one of the competencies that are of prime importance in the engineering industry. The fact that engineers' overall work time is spent on some form of communication has strongly proven that the needs of this skill in the engineering workplace.

The study of Sageev and Romanowski (2001) claims that "technical ideasi and results are not useful until and unless they are communicated and discussed” (p. 687).

Raha, Radzuan and Kaur. (2010) state that "a stronger emphasis on communication abilities 
while still attending university is also recommended as part of university's responsibility in preparing students for the workplace. Engineering students must spend more time on formal oral communications in English for them to enhance their mastery in the target language. Findings in this study reported that public speaking or giving formal oral presentations caused high apprehension among majority of the engineering students. Therefore, the content of incorporating a communication curriculum should not only include, but also stress on oral presentations. Opportunities to practice giving presentations inside and outside the classrooms are crucial for their future employment success. Students need to practice receiving more feedback from their course instructors. These skills are important as engineers' job specifications require engineers to communicate their ideas clearly to clients, colleagues and management" (pp. 9-10).

Venkatraman and Prema's (2007) in their research study state that educational achievement and future career can be influenced by grip or fluency of students in English.

Another study conducted on workplace communication by Kaur and Lee (2003) summarizes that in the IT industry recruitment policy, the oral communication skills in English is the chief criteria that the employers identified presentation, communicative skills and interviewing in English as being main qualities for IT graduates.

In addition, Adler \& Elmhorst (2002, as cited in Kaur \& Lee, 2003) describe that "the system of communication networks provides information on the communication patterns among people in organizations of various status and situations that exist in the workplace. They suggest that the two common networks are the formal communication network (comprising three types of communication: downward, upward and horizontal communication) and the informal communication network (arising from personal interest, friendships and shared office space)".

\section{Methodology}

In the current study, quantitative method was used to conduct a survey through random sampling to measure communication apprehension among respondents. An adapted version of the personal report of communication apprehension (PRCA-24) instrument (McCroskey 1982) used for conducting data. In this study, the survey was conducted firom the students of Mehran University of engineering and technology.

\subsection{Data Collection Tool}

McCroskey version of the PRCA-24 was adapted, 18 items were selected according to requirement of this study. The questionnaire was based on twenty-four statements regarding participants' feelings while communicating in the four communicative tasks: group discussions, meetings, interpersonal conversations, and public speaking. The "meeting" section was omitted. The questionnaire was used to measure the participant's communication apprehension in these areas.

The Questionnaire was built on the 5 Likert scale from Strongly Agree $=5$ to strongly Disagree $=1$. The participants were required to answer to the statements while choosing the 
corresponding number of the option that they felt the most relatable to express their opinions with respect to the communication.

\subsection{Participants}

Personal Report of Communication Apprehension (PRCA-24) aimed to determine students' level of communication apprehension in various contexts. 120 engineering, students of MUET were included in this survey study. The students were selected through random sampling. All questionnaires were returned with complete answers.

Confidentiality and anonymity were assured to participants for their responses. Participants were not asked to mention their personal information on the survey forms and they were assured that the data would only be used for research study .

\subsection{Data Analysis}

Data was analyzed through SPSS statistical software in descriptive and frequencies.

\section{Findings and Discussion}

The findings of the study show that the students have high communication apprehension during participating in public speaking and formal discussions.

Table 1. Frequency of Gender

\begin{tabular}{llllll}
\hline & & Frequency & Percent & Valid Percent & Cumulative Percent \\
\hline Valid & Female & 15 & 12.6 & 12.6 & 12.6 \\
& Male & 104 & 87.4 & 87.4 & 100.0 \\
& Total & 119 & 100.0 & 100.0 & \\
\hline
\end{tabular}

This Table 1 shows the percent of participants who participated in the study. Data was collected from an engineering University; therefore number of female participants was small. $12 \%$ of female students participated while percent of male students participants was $87 \%$.

Table 2. Frequency of departments

\begin{tabular}{llllll}
\hline & & Frequency & Percent & Valid Percent & Cumulative Percent \\
\hline Valid & CE & 43 & 36.1 & 36.1 & 36.1 \\
& TL & 25 & 21.0 & 21.0 & 57.1 \\
& ES & 23 & 19.3 & 19.3 & 76.5 \\
MT & 28 & 23.5 & 23.5 & 100.0 \\
& Total & 119 & 100.0 & 100.0 & \\
\hline
\end{tabular}

Table 2 below displays the number of student participants who were randomly selected from 
different departments.

Table 3. Number and percentage of respondents who are classified as high, moderate or low on PRCA total scores

\begin{tabular}{ll}
\hline Respondents & Scale \\
\hline High communication apprehension & $44(31.4 \%)$ \\
Moderate communication apprehension & $30(21.4 \%)$ \\
Low communication apprehension & $66(47.1 \%)$ \\
\hline
\end{tabular}

Table 3 shows that almost $47 \%$ of respondents reported having low communication apprehension while $44 \%$ respondents perceived themselves as having high communication apprehension. The table data also reveals that small number of the respondents $(21.4 \%)$ reported for moderate communication apprehension.

Analysis was also done for the subscores of each scale. Table 3 below illustrates the high and low communication apprehension experienced by respondents and its number based on the PRCA subscores.

Table 4. Number and percentage of respondents who classified as high or low on PRCA subscores

\begin{tabular}{llll}
\hline Scale & High & Moderate & Low \\
\hline Public speaking & $62(41 \%)$ & 34 & $44(29 \%)$ \\
Group discussions & $28(18 \%)$ & 27 & $85(56 \%)$ \\
Interpersonal conversation & $42(28 \%)$ & 29 & $69(46 \%)$ \\
\hline
\end{tabular}

The data revealed high communication apprehension in the domain of public speaking, for a majority of respondents is $62 \%$. In Group Discussions, the sub score data indicated that most respondents experienced low communication apprehension in this context $(28 \%)$. Interpersonal Conversations subscore data shown that 42 and 69 students respectively had high and low levels of communication apprehension.

\section{Implications of Findings}

This study makes the educators and course designers aware of the main lacking point and encourages to take certain efforts to prevail over the shortcoming. Communication skills are highly needed in every field specially in the workplace, it may be for job recruitment or job promotion. One of the most crucial jobs of university administrators is to train the students enough for hiring in different workplaces. Students should be provided more opportunities for presentations or platform to improve speaking skills because these are very essential for employment success. Students also need to practice more on the feedback received from their 
instructors.

\section{Conclusion}

In the present study, the researchers come to the conclusion that the students of engineering university experience communication apprehension high in the context of public speaking, followed by interpersonal conversation and group discussion. There is a need of deep insight into this area across different universities in Pakistan.

\section{Recommendations}

According to results and context of study, the teachers who are dealing with teaching communication skills must consider and observe the needs of students and give them practical situation out of classroom environment so that they can improve their apprehension. The ELT teachers should devise task-based activities and provide mock environment for communication.

\section{References}

Almeida, E. P. (2004). A discourse analysis of student perceptions of their communication Competence. Communication Education, 53(4), 357-364. https://doi.org/10.1080/ 036345203200305968

Amogne, D., \& Yigzaw. (2013). Oral communication apprehension, competence and Performance among maritime engineering trainees. Journal of Media an Communication Studies, 5(1), 5-11.

Crosling, G., \& Ward, I. (2002). Oral communication: Workplace needs and uses of business graduates employees. English for Specific Purposes, 21, 41-57. https://doi.org/10.1016/ S0889-4906(00)00031-4

Devi, S., \& Feroz, F. S. (2008). Oral communication Apprehension and communicative competence among Electrical Engineering Undergraduates in UTEM.

Kaur, S., \& Lee, S. H. (2006). Analysing workplace oral communication needs in English among IT graduates. English for Specific Purposes World, 5.

Kaur, M., Singh, M., David, R. A., \& Choo, C. (2011). Communication apprehension among international undergraduates: the impact on their communicative skills. Modern Journal of Language Teaching Methods (MJLTM), 1(2).

MacIntyre, P. D., \& Noels, K. A. (1997). Biases in self-ratings of second language proficiency: The role of language anxiety. Language Learning, 47(2), 265. https://doi.org/10.1111/0023-8333.81997008

Mark, A. T. J., \& Ronald, C. S. L. (2016). Relationship between Teacher Education Students' Oral Communication Apprehensions in English and Their Academic Performance. International Journal of Languages, Literature and Linguistics, 2(2). https://doi.org/10.18178/IJLLL.2016.2.2.69 


\section{Macrothink}

Education and Linguistics Research

ISSN 2377-1356 2019, Vol. 5, No. 1

Raha, N., Radzuan, M., \& Kaur, S. (2010). A Survey of Oral Communication Apprehension in English among ESP Learners in an Engineering Course. English for Specific Purposes World, 31(10).

P'Rayan, A., \& Shety, T. (2008). Developing Engineering Students' Communication Skills by Reducing their Communication Apprehension. English for Specific Purposes World.

Rosenfeld, L. B., Grant III, C. H., \& McCroskey, J. C. (1995). Communication apprehension and Self-perceived communication competence of academically gifted. Communication Education, 44(1), 79. https://doi.org/10.1080/03634529509378999

Sarjit, K., \& Lee, S. H. Analysing workplace Oral Communication Needs In English Among IT Graduates. English for Specific Purposes World.

Sageev, P., \& Romanowski, C. J. (2001). A message from recent engineering graduates in the workplace: Results of a survey on technical communication skills. Journal of Engineering Education, 685-693. https://doi.org/10.1002/j.2168-9830.2001.tb00660.x

Thaher, M. (2005). Communication Apprehension among An-Najah National University Students. Palestine: An-NajahUniv.J.Res. (H.Sc.), 19(2).

Venkatraman, G., \& Prema, P. (2007). English language skills for engineering students: A needs survey. ESP World, 3(16).

\section{Copyright Disclaimer}

Copyright reserved by the author(s).

This article is an open-access article distributed under the terms and conditions of the Creative Commons Attribution license (http://creativecommons.org/licenses/by/3.0/). 